\title{
The language learning experiences of students with dyslexia: Lessons from an interview study
}

Judit Kormos $^{\mathrm{a}}$, Ágnes Sarkadi ${ }^{\mathrm{b}}$ and Kata Csizér ${ }^{\mathrm{b}}$

${ }^{a}$ Department of Linguistics and English Language, Lancaster University, Lancaster, United Kingdom; ' ${ }^{b}$ Department of English Applied Linguistics, Eötvös Loránd

University, Budapest, Hungary

Published in: Innovation in Language Learning and Teaching, Volume 3, Issue 2 2009 , pages 115 - 130

\begin{abstract}
Our interview study investigated what experiences Hungarian students with dyslexia have in the language learning group and concerning the general behavior, the instructional methods and assessment techniques of their language teachers. Long qualitative interviews were conducted with 15 students of different ages who studied foreign languages in a variety of educational settings. Our results indicate that the participants generally had negative experiences when studying in groups especially if the number of students in the group was high, but they enjoyed when they received special attention and the rate of progress was adjusted to their needs. Students with dyslexia were found to be highly appreciative of clear and well-structured explanations and frequent revision opportunities. The students' views confirm the high importance of applying motivational teaching strategies in teaching foreign languages to students with dyslexia and the existence of an indirect link between teachers' attitude to dyslexia, teacher behavior and language learning effort.
\end{abstract}

\section{Keywords}

Dyslexia, language learning attitudes, teacher behavior, motivational strategies

\section{Corresponding author}

Judit Kormos j.kormos@lancaster.ac.uk 


\section{Introduction}

In this age of globalization and in most countries of the world, people who do not speak a second or a foreign language are at a serious disadvantage in the job market and sometimes even in their private sphere of life. In the European Union, for example, the requirement agreed on by the Community in 1995 is that all its citizens should acquire proficiency in at least two foreign languages. It is therefore of great relevance that learners with special educational needs are also provided with equal and appropriate opportunities to learn a second or foreign language. Most language teachers, however, are not in the position to cope with the special needs of these students for several reasons. First of all, they frequently lack the knowledge about the nature of their students' special educational needs. Secondly, they are not aware of affective and cognitive strategies which disadvantaged students use to overcome the difficulties that language learning poses for them. Finally, teachers are not equipped with the appropriate language teaching tools including techniques, tasks and materials, to help these learners (Smith 2008). Despite the apparent need for studies on the process of language acquisition for learners with special needs, the field of second language acquisition has neglected language learners with dyslexia. Most of the research in this field has concentrated on the cognitive and linguistic differences between students with learning disabilities (LD) and learners with no apparent sign of LD and has been quantitative in nature (for recent studies see Ndlovu and Geva 2008; Sparks, Ganschow, and Patton 2008). Although it is important to understand the language processing differences between students with LD and no LD, gaining an insight into the language learning experiences of dyslexic students also has great 
relevance for the language teaching profession. The perspectives of students with dyslexia can help teachers understand what kind of experience it is to study a foreign language when one has reading disability and what kinds of teacher behavior, teaching techniques and methods of assessment might assist these learners to successfully acquire an L2.

The situation of dyslexic students Hungary is interesting for a number of reasons. First of all, the orthography of the Hungarian language is highly transparent; therefore a high number of dyslexic students with good compensatory skills remain undiagnosed, and their reading disability only becomes apparent when they start learning foreign languages, especially English (Gyarmathy and Vassné Kovács 2004). The other reason is that Hungary is largely dependent on international investments and foreign trade; therefore it is almost impossible to find a well-paying job if one does not speak at least one foreign language. In addition, a certificate of intermediate level of proficiency in a foreign language is also a pre-requisite for obtaining a university degree.

The aim of our study was to provide an insider's account of the language learning experiences of Hungarian students with dyslexia. For this purpose we conducted long qualitative interviews with 15 students who studied foreign languages in a variety of educational settings such as mainstream schools, schools specialized in learning disabilities and courses in language schools. The participants also varied as regards their age, profession and the time of diagnosis of their dyslexia. We hope that the large variety of participants can give a comprehensive overview of what kind of experience it is to study an L2 in a foreign language setting when one has dyslexia. We also believe that since language teachers in many other parts of the world rarely receive training in teaching foreign languages to students with LD (see Smith 2008), 
our results are also relevant for the field of language pedagogy in a number of countries.

\section{Background to the study}

Although the field of dyslexia and learning disability research has been plagued by a lack of agreement on what dyslexia and learning disabilities are, the definition of the International Dyslexia Association, which we endorse for the purposes of the present study, seems to represent a consensus in the field (see e.g. Fletcher, Lyon, Fuchs, and Barnes 2007):

Dyslexia is a specific learning disability that is neurobiological in origin. It is characterized by difficulties with accurate and/or fluent word recognition and by poor spelling and decoding abilities. These difficulties typically result from a deficit in the phonological component of language that is often unexpected in relation to other cognitive abilities and the provision of effective classroom instruction. Secondary consequences may include problems in reading comprehension and reduced reading experience that can impede growth of vocabulary and background knowledge (cited in Lyon, Shaywitz, and Shaywitz 2003, 1).

Dyslexic learners are likely to encounter a large number of problems when learning foreign languages (Downey, Snyder, and Hill 2000; Ganschow, Sparks, and Javorsky 1998; Kormos and Kontra 2008; Sparks et al. 2008). Moreover, students with dyslexia often suffer from their environment's reaction to their special situation as well. Ignorance about learning disabilities also aggravates the situation of dyslexic students. Most people have vague ideas about the causes of dyslexia, and they often consider it a sign of low intelligence (Ranaldi 2003), which results in the 
stigmatization of dyslexics (Gyarmathy and Vassné 2004). Edwards' (1994) study illustrates the negative experiences of dyslexic students at school and reveals that even successful and confident dyslexic students experience unfair treatment, discrimination, neglect and humiliation during school years (see also Sarkadi 2005).

Linguistic problems and the negative experiences in the foreign language lessons also decrease the language learning motivation of students with dyslexia (Kormos and Kontra 2008). As 'the education-friendly' approaches in motivation research emphasize, teachers play an essential role in motivating students (Brown 1990, 1994; Crookes and Schmidt 1991; Dörnyei 1994, 2001a; Oxford and Shearin 1996; Schmidt, Boraie, and Kassabgy 1996; Williams and Burden 1997). Empirical evidence for teachers' behavior affecting students' motivation was provided by Noels, Clément and Pelletier (1999), who investigated how teachers' communicative style was related to L2 motivation. Their results showed that extrinsic and intrinsic motivation was influenced by the teacher's communicative style to a different degree. In a longitudinal qualitative study conducted in a Hungarian primary school, Nikolov (1999) found that that children were mainly motivated by factors associated with the classroom situation (i.e., positive attitudes towards the learning context and the teacher as well as intrinsically motivated activities, tasks, and materials). In connection with students' losing their motivation to learn the foreign language, Dörnyei (2005) pointed out that "the majority of demotives identified in past research concern some aspects of classroom experience 'owned' by, or under the control of, the teacher" (p. 90). In line with this, one of the aims of the 'educational shift' in the L2 motivation field has been to give teachers practical help on how to arouse and sustain students' motivation. To fulfill this aim, various lists of motivational strategies were compiled based on teaching experience and existing literature (e.g., Brown 
1994; Dodick 1996; Dörnyei 1994, 2001b; Dörnyei and Csizér 1998; Oxford and Shearin 1994; Williams and Burden 1997).

Our study is novel in several respects. Language learners' perspectives of the circumstances of their learning processes in foreign language classrooms have not yet been explored despite the fact that information about students' learning experiences can greatly contribute to effective and motivating instructional practices. Our participants constitute a special group of students: learners with dyslexia, for whom motivational teaching is highly relevant in order to compensate for their effortful and often problematic language learning processes. The research presented in this paper seeks to answer the following questions:

1. What characterizes the language learning experiences of dyslexic students concerning the group they study in?

2. How do dyslexic students view their teachers' general behavior and instructional and assessment methods?

\section{Research method}

Participants

Some of the participants volunteered for the interviews in response to an advertisement recruiting dyslexic language learners who were willing to speak about their language learning experience. Other respondents were recommended by teachers or speech therapists working with dyslexic students. All students held an official document that certified the diagnosis of dyslexia. The students' dyslexia was identified with the use of the GMP test (Gósy 1995) and Meixner's reading test (published in Juhász 1999). ${ }^{1}$ Meixner's reading test consists of a letter naming, a syllable reading, word reading and a short-text reading task, which are all scored in 
terms of speed and accuracy. The criterion for being identified as dyslexic is that the student achieves a score that is below the established standard on both of these tests. In the interviews the participants all reported experiencing severe difficulties in acquiring literacy skills in their first language, which further supports the fact that they can indeed be considered dyslexic. We tried to achieve maximum variety in sampling the participants; therefore in selecting the interviewees, we considered their age, age of identification, level of language knowledge and the therapy they received in their native language. The participants also differed in whether their problems were attended to by their foreign language teachers. Table 1 summarizes the relevant characteristics of the participants. Out of our 15 respondents five were girls, 10 boys with an average age of 18 . The majority of them (12 participants) was learning English as a first foreign language, and the three participants whose first L2 was German also took up English during their studies. Despite foreign language learning difficulties, there was only one student who did not study a second foreign language (L3). It has to be noted that in Hungary students in elementary school (between the ages of 7 and 14) are obliged to study one foreign language, and above the age of 14, in secondary school they have to choose an additional foreign language. ${ }^{2}$ Dyslexic students can, however, be exempted from studying a second foreign language. The average age of diagnosis was 13.7 years, which indicates that most of our respondents had to study a foreign language at school without their and their teachers' being fully aware of their dyslexia. As can be seen in Table 1, 8 participants attended mainstream primary and secondary schools, and one student went to a mainstream primary school, which, however,had special classes for students with LD. One of the participants studied in a mainstream secondary school, in which there was a special language teaching program for learners with LD. Two interviewees attended a special 
combined primary and secondary school for learners with LD, and three students attended a special secondary school for learners with LD.

\section{INSERT TABLE 1 HERE}

\section{Procedures}

The research presented in this paper is part of an extensive interview study, which investigated Hungarian dyslexic students' feelings and experiences about language learning and examined the language learning strategies these students applied to overcome their difficulties in language learning. The interview guide used in the extensive research was compiled on the basis of the relevant literature concerning the experiences, difficulties and learning strategies of dyslexic learners (Kormos and Kontra 2008; Ormos 2004; Schneider and Crombie 2003; Sparks and Ganschow 1993).

The interview guide consisted of 15 questions, which focused on four main topics: participants' problems in every day life and in the native language resulting from their dyslexia, language learning experiences, language learning difficulties and coping strategies and motivational characteristics. The instrument was piloted with two students, and minor modifications were made to the interview guide after piloting. The interviews were conducted in Hungarian and lasted for approximately 40 minutes. The interviews were recorded and transcribed by one of the authors and a trained research assistant.

The interview transcripts yielded about 60,000 words of data, which were first analysed independently by the three authors for the themes related to our research questions. Once the themes found relevant by all the researchers were agreed on, 
definitions of the categories of analysis were worded based on the analysis of the first five interviews. The first two authors then coded all the utterances separately, following which certain modifications were made in some of the categories, and the wording of the definitions was fine-tuned. Discrepancies between the analyses of the two authors were discussed until a full agreement was reached. In analyzing our data we used the data analysis software MAXQDA 2007. The analyses yielded the following categories:

1. Experiences in the learning group - students'views and experiences with other learners in the group, their role in the group e.g. "I was afraid of making mistakes in front of the others and being laughed at" (L1767).

2. Attitudes to the teachers

a) The teacher's general behavior in class - overall opinion about the teacher's personality and general conduct in class e.g. "She only liked students who were bright and easy to deal with, and those who were the difficult cases were failed." (P82)

b) The method of teaching/tasks/materials used in class - comments related to what methods, tasks and materials the teacher used in the foreign language class e.g. "The lessons were not interesting; we always followed the book and sometimes we solved tasks on photocopied sheets.” (P102)

c) Assessment - grading, error correction, dyslexic accommodations e.g. "My teacher deducted points in tests for incorrect spelling, but I did not mind because I usually got good grades anyway.” (B327)

\section{Results and discussion}

Experiences in the learning group 
Due to their dyslexia, many of our participants had negative experiences in the language learning group, which in the Hungarian context generally means half of a class as students study foreign languages in groups of 10-15. The students' difficulties in learning in groups in mainstream education were mainly caused by their different pace and style of learning. One of the participants told us that:

I have attended various courses. In groups where there were many students no attention was paid to individual needs; the teacher taught the material and everybody tried to learn as much as they could. After a while I was the last one in the group, and I said thank you, I am not coming any more. Then I went to a course with a small group. There the problem was that we were not at the same level. So people who had no difficulties learnt the material very easily, and then I was lagging behind the others again. (B477-478)

This quote suggests that many students with dyslexia find it difficult to follow the general pace of teaching in language courses because "students with dyslexia have different abilities and skills than other learners, and therefore they acquire the same knowledge in different ways" (D647). Therefore they feel that they lag behind the others, and that they are left alone in this difficult and effortful learning process. The constant sense of failure in a group might finally result in giving up learning languages altogether or in a better case, students might continue studying with a private tutor, which as shown below, many of our participants found useful and enjoyable. Being paid attention to is an aspect of teaching that students with dyslexia regard very important (see below), therefore the participants who were learning in groups at school preferred small group size.

In elementary school there were 25-30 students in the German group, and the teacher could not pay close attention to individual students. So I like English 
better because here there are only 11 students, and the teacher pays more attention. (M2142)

The experiences of some of our participants who study in schools specialized in LD are slightly different. Two of our interviewees in specialized schools did not mention any problems they experienced in learning in groups, which in all likelihood is due to the fact that their special needs and individual strengths and weaknesses were taken into account. Two of the students in a specialized school setting, however, had relatively higher levels of proficiency than their peers due to family resources and their increased interest in languages. These learners could not participate in the life of the group because the language teacher did not use differential teaching in the classroom. As one of them told us, "if I was asked questions, I answered, otherwise I slept, I was daydreaming and sometimes studied other subjects.” (N1513). This indicates that dyslexic students have different language learning profiles and abilities, and even if they study in compensatory classes and in specialized schools, their individual needs and proficiency level need to be taken into consideration.

Another student who was exempted from the evaluation of her performance in foreign languages in a mainstream school complained about the lack of understanding on the part of her peers. This quote below illustrates that for many dyslexic students who study in mainstream classrooms exemption from language learning is not a relief, but an emotional burden:

It is not the teachers who are upset about my exemption but the students. They think that this is a kind of alibi, and it is easier for me. This is not true, it is really a burden that there is a thing that you will never really be able to do well in your life. (H1130). 
Positive experiences relating to the language learning group were hardly ever mentioned by our participants in mainstream education. Only two interviewees expressed the view that the group they study in is motivating, and as their peers take learning seriously, they also invest a sufficient amount of energy into studying.

The interview data indicate that the different learning profile of the interviewed dyslexic students causes problems for most of them when they study in groups. If they learn in a mainstream school or in a commercial language course, they cannot keep pace with other group members, and they lack the attention of the teacher. In mainstream schools, students also experience the lack of understanding on the part of their peers, which might seriously undermine their self-confidence and might finally lead to giving up language learning. On the other hand, in specialized schools the needs of proficient learners are not catered to. It is probably partly due to these group-related experiences that most of our interviewees preferred learning languages with a private tutor (see below).

Teachers' general behaviour, instructional practices and assessment

When examining students' views of their language teachers' general behaviour and instructional practices in class, we analyzed the students' comments concerning their private tutors and their language teachers at school separately. First we discuss students' general experiences with their language teachers at school.

Our data reveal that dyslexic students have a "black-and white" picture of their teachers, they either display a rather negative attitude to them or a fairly positive one. Students' utterances concerning their teachers' personality and general conduct in class either fell in the category that denoted students' approval and appreciation of 
their language teachers (positive attitude e.g. "I have a private teacher, who is excellent. I really like her. (H1092)), or in the one that contained comments expressing disapproval and dissatisfaction (negative attitude e.g. "The teacher does not like me because I am not good at English. So I don't like her either” (J1393)). No neutral comment was found in the data set. Our interviewees made exactly the same number of positive and negative comments concerning their language teachers at school $(N=28)$. If we examine the number of respondents' comments individually, we can see that altogether 3 out the 15 students did not express negative attitude to their teachers. It seems that probably due to their learning problems, our participants are very sensitive to their teachers' general behaviour in class. As we will show below, if they find that their teacher accepts their dyslexia and is helpful, they have positive attitude towards them, but when they experience lack of understanding, intolerance and sometimes humiliation, they display negative views.

\section{INSERT TABLE 2 HERE}

Students' negative views concerning their teachers' behaviour covered a range of issues. One of the participants told us that his language teacher recommended that he got an exemption from language learning. The teacher's referral to the educational advisory centre was made due to the student's behaviour in language class ("The German teacher said that she cannot tolerate my and three of my mates behaviour anymore, and we should go and get an exemption in this and that street where the education advisory centre is" A43-44). The situation of this student illustrates that students with dyslexia often misbehave in foreign language classes due to their constant experience of failure and the teacher's inappropriate reaction to their learning disability (Kormos and Kontra 2008). One possible reaction on the part of the teacher 
to this situation can be exempting the student, which solves the problem of misbehaviour for the teacher, but it seriously disadvantages the student.

Teachers' negative reaction to dyslexia manifested itself in different ways. One of the interviewees who was a late identified dyslexic recounted the experience when his first teacher told him "that's it for you, you are going to fail" (F816). This incident had serious detrimental effect on the student's attitude to language learning and his motivation to study English. Another student explained that "they did not try to help me, but they emphasized that I am having problems, but not like wanting to help me but as a kind of humiliation" (H1061). She also mentioned that her language teacher regarded her exemption from language learning as an excuse that she did not have to deal with the student's language learning problems. One participant told us that despite the fact that his parents consulted with the English teacher concerning his dyslexia, she still did not take it into consideration; in the student's words: "she did not care" (J1407). These instances of negative teacher behavior illustrate the lack of the teacher's awareness of the nature and severity of problems dyslexia can cause in language learning, which in turn can increase the stress and anxiety a dyslexic student might experience in the foreign language classroom.

In contrast with the varied nature of negative views concerning the teachers' behavior, the positive comments centered around very similar themes. Several interviewees mentioned that their teacher was helpful $(N=4)$, kind and friendly $(N=$ $3)$ and paid special attention to them $(N=4)$. From the comments it is apparent that a helpful attitude and special attention to the student was very highly valued by the participants. Other positive characteristics of teachers included being reasonably strict and demanding. The characteristics the students listed mainly belong to what Brophy (1987) calls essential pre-conditions for motivational teaching practice and indicate 
the importance dyslexic students attribute to supportive teacher attitude in the language learning classroom.

As regards their private teachers' general behavior, all the comments of the eight students who had private tutors were positive. The participants found that the pace of learning was adjusted to their needs: "I could study at my own pace, and the teacher adapted to me, and it was not me who had to adapt." (N2242) The importance of being able to study at their own pace is also confirmed by interviews conducted with language teachers, who all mentioned that students with dyslexia are slower in language learning in general due to problems in memorizing L2 words, word decoding, global text comprehension, writing and spelling (Kormos and Kontra, 2008). As we have shown above, the learning experiences of dyslexic students in a group are often negative because they cannot keep up with the progress of their peers, and therefore it is understandable that they enjoy learning with a private tutor, from whom they get all the attention and who adjusts the pace and teaching materials to their needs.

Among the utterances describing the language teaching methods of school teachers, we find negative comments concerning the teacher's ability to explain linguistic rules $(N=3)$ and the lack of interesting tasks and texts $(N=2)$. Two students mentioned that they only studied grammar, which they found very boring, and another two participants noted that they had to rote learn a lot of irrelevant words out of context. Three participants told us that the school teacher was progressing too fast, and they were unable to acquire the taught material within such short period of time. The positive comments expressed exactly the opposite, namely the teacher's skill in explaining the rules of the language, interesting tasks and materials, and slow pace of learning. 
Concerning their private teachers, the participants also noted that what they valued was that their tutor could explain things very well. They also mentioned that their teacher helped them to achieve that "whatever they study is really deeply learned, and it does not become some sort of superficial knowledge" (B464). Another participant explained that she liked that "the teacher revises the material several times" (H1093). Three of the participants had a private tutor, who had formal training in teaching languages to students with dyslexia, and these interviewees all found that the "dyslexic teaching techniques" such as multi-sensory instruction (MSL) (Sparks et al. 1998; Nijakowska 2008) were very helpful. The students' views of what they consider important and useful in the teaching practice of their private tutors are very similar to what language teachers working with dyslexic students regard as essential (Kormos and Kontra, 2008): namely slow, step-by-step acquisition of linguistic constructions and L2 vocabulary, and constant revision. These essential components of teaching foreign languages to dyslexic students are also part of MSL instruction. Students' enhanced need for clear explanations both in school and private language lessons can probably be explained with reference to the fact that students with dyslexia find it very difficult to deduce linguistic rules from the input (Schneider and Crombie 2003). Therefore whether they understand the use of a given linguistic construction is largely dependent on how their teacher can explain it to them.

As regards the assessment of the performance of students with LD, we found several different cases. In the case of two participants, teachers did not take into consideration the student's dyslexia in assessment, which resulted in low grades and a large discrepancy between their performance in written and oral tests. Among the participants whose dyslexia was identified only when they finished their studies in public education, one student compensated for her dyslexia by studying extremely 
hard, therefore she did not mention negative experiences with assessment. The other interviewee told us that despite being an excellent student in other subjects, she failed in English in secondary school. She had to retake all the subjects of the second year of grammar school just because she was not able to pass the end of year retake exam in English. She described the experience in the following words, "In the other subjects I had really good grades, so the teachers did not understand this whole situation. Neither did my school-mates." (C468). There was only one student who despite being entitled to accommodations in language learning, did not take advantage of them because he felt that he did not need them.

As we mentioned above, the teacher of one of our participants did not consider the student's dyslexia in assessment despite the recommendations of the educational advisory center and the parents' explicit request. As a result of this unfair treatment, the student started to develop classroom language learning anxiety (Horwitz, Horwitz \& Cope, 1986):

Before the lessons I always look for the teacher in the corridor. I always hope that she won't come. The other thing that I always check is whether she has brought some tests with her. (J 1352)

Three of our participants were completely exempted from the evaluation of their performance in language classes. Only one of the teachers of these three participants made the student write the tests in class and corrected them without grading them. The rest of the teachers regarded exemption as an official excuse not to have to deal with the student in the foreign language class, which reveals that a number of language teachers are not prepared to handle the problem of exemption in a way that benefits the learners. Five of the students received accommodations, which either entailed an exemption from the evaluation of their written work in general or 
not considering spelling in evaluation. All the participants who received these accommodations found them as means of appropriate help in their language studies. One of our interviewees expressed her opinion about this in the following way: My Hebrew teacher did not get any training in teaching dyslexics, but he does not consider spelling and that's it. This was all I needed and now I can speak one more language... So if your spelling is not assessed, it will be easier for you, and you don't have butterflies in your stomach anymore that my God, I have to get this right. Once you are relieved of this stress, you will do better. It will be much better. (I1286-1288)

The comment of this participant reveals that for dyslexic students written assessment, especially the grading of spelling, might be an important source of language learning anxiety, and often once this stressor is removed, they can achieve success in language learning.

Our participants' views concerning their language teachers' general behavior, teaching and assessment practices reveal that students with dyslexia are very sensitive to and well aware of what constitutes effective teaching practice. If we compare features of teacher behavior and instructional methods mentioned by our interviewees with the list of elements of motivational teaching practice (Dörnyei 2001a) and effective teaching (Brophy 1987; Creemers 1994), we can find a large overlap. From the lists proposed in the general educational literature and language pedagogy, our dyslexic participants highly value teacher enthusiasm, supportive attitude, opportunity to learn, appropriate goal setting, relevant and interesting teaching materials, clarity of presentation, appropriate pace of learning and assessment methods that are adjusted to their disability. The interviewees also discussed how teacher behavior and instructional practices affected their attitudes to language learning and self-perceived 
rate of progress. When working with a teacher, whom they considered effective, a number of participants $(N=4)$ expressed that the teacher had a positive effect on their attitudes to language learning and in turn on their self-perceived rate of progress (e.g.,"I had an excellent language teacher. When she was my teacher, I really liked English and I progressed a lot.” (J1341).

When conflicts arise, we can see the opposite effect:

I did not get on well with the German teacher. It was not only me who had problems, but the whole class. Her methods of teaching were not the best. This is why I found German classes difficult to follow, and learning the language was difficult overall. So I did not like learning German" (F587).

Another participant used even stronger words to explain the relationship between teacher behavior and language learning attitudes: "She does not teach well. She kills the love of the language in the students." (H1149). Our qualitative data indicates a strong causal relationship between teacher behavior and language learning attitudes and also reveal that language learning attitudes influence motivated behavior (for more detail on the relationship of motivation and teacher behavior, see Kormos, Csizér and Sarkadi, submitted ). As one of our interviewees said, "I lost interest in the language due to the teacher in secondary school, and so I did not really study much" (D532).

An emerging model of the language learning experiences of students with dyslexia

From our analysis of the interview data, we can see an emerging model of the language learning experiences of dyslexic students. Our qualitative results suggest that the major factor that serves as primary determinant of the language learning 
experiences of dyslexic students is the teacher's attitude to dyslexia. This includes the teacher's awareness of the nature of problems dyslexia causes in language learning and attitudes to accommodations and exemptions available for dyslexic learners. The teacher's attitude to dyslexia influences the basic motivational conditions that are created by the teacher in the language classroom (see Dörnyei 2001b). Among the basic motivational conditions, supportive atmosphere and special attention to the dyslexic students as well as the methods of assessment and teaching were perceived to be the most important by our participants. From the students' experiences it is apparent that if teachers are unaware of the problems dyslexia causes or refuse to take into account the students' reading disability, the basic motivational conditions cannot be established and testing and instructional procedures cannot be tailored to the students' needs. ${ }^{3}$ Based on the literature on language learning motivation (e.g. Guilloteaux and Dörnyei 2008; Nikolov 1999) and on our interview data, we can also hypothesize that the extent to which teachers are able to employ elements of motivational teaching practice has an influence on students' self-confidence and language learning anxiety (Price 1991) and through these on their language learning attitudes (see also Kormos et al., submitted). Finally, language learning attitudes affect motivated behavior, that is, the effort and energy students are willing to invest in language learning (see also Dörnyei, Csizér, and Németh 2006). INSERT FIGURE 1 AROUND HERE

\section{Conclusion and implications}

In this paper we investigated the language learning experiences of Hungarian dyslexic students by means of long interviews. Our data reveal that the participants generally 
had negative experiences when studying in groups especially if the number of students in the group was high. They explained that due to their specific difficulties with language learning, they could not keep pace with the other group members; therefore they often felt isolated and sometimes even opted out from learning. A complementary finding of our research is that most participants enjoyed working with a private tutor because they received special attention and the rate of progress was adjusted to their needs. The students' own perceptions of how they can learn an L2 most effectively are in line with language teachers' views in another Hungarian study (Kormos and Kontra, 2008). On the basis of both the present study and the one conducted with teachers, we can conclude that it is highly important that special compensatory groups should be formed for dyslexic learners where they can gain enough input, practice, knowledge, positive feedback and confidence (see also Nijakowska 2008 for similar views in the Polish context). In mainstream education, compensatory classes in a foreign language should be provided for students with dyslexia at the primary and secondary school levels and in higher education if the institution sets foreign language proficiency as a requirement. Alternatively, dyslexic students should be taught foreign languages in special groups where specific methods (e.g. multi-sensory instruction) that foster the development of L2 competence of dyslexic students are applied.

The interview data reveal that students with dyslexia are highly appreciative of positive teacher behavior and motivational instructional processes. Negative teacher attitudes and inappropriate teaching methods, however, can seriously undermine students' self-confidence and might cause language learning anxiety. The deterioration of self-esteem and an increased level of anxiety might in turn result in negative attitudes to language learning and lack of motivated behavior. The students' 
views confirm the high importance of applying motivational teaching strategies in teaching foreign languages to students with dyslexia and the existence of a an indirect link between teachers' attitude to dyslexia, teacher behavior and language learning effort. In all probability, these results are not unique for students with dyslexia. Our research, however, suggests that among components of effective teaching practice, clear and well-structured explanations and constant revision received special emphasis in dyslexic students' evaluation of their language instruction. The students' views also show that adjusting the assessment procedures to the nature of the learner's disability is also important as even minor accommodations can help students to achieve to their best potential, which in turn reduces their anxiety and enhances their attitudes to language learning.

Our study highlights that it is of vital importance that language teachers be aware of the fact that a child or an adolescent is dyslexic and that they also know what difficulties dyslexia causes in the language learning process. Therefore, language teacher education should include at least a brief introduction to the nature of learning and more specifically reading disabilities and an overview of instruction and assessment techniques that can be used in teaching foreign languages to students with dyslexia.

\section{Acknowledgements}

The authors are grateful to the participants who devoted their time to sharing their experiences with us. We thank Éva Gyarmathy and Eszter Bakos for recruting participants. The research reported in this paper has been sponsored by the Equal Rights in Foreign Language Education project of the Hungarian National Bureau of Research and Technology (NKTH B2 2006-0010). 


\section{Notes}

1. The Hungarian data protection law does not allow access to student's psychological tests for out-side school use. Therefore we could only verify the existence of the diagnosis but were not able to collect information on diagnostic test scores.

2. Many of our participants gave up learning one foreign language in the hope that they will succeed in the other one. Some of the interviewees had to choose another language because they changed school, and the new school did not offer the language the student previously studied. This explains the high number of students who studied two foreign languages.

3. There was only one exception to this among our interviewees: a late identified student who was driven by her intrinsic motivation to acquire English, and who despite the fact that her teachers were unaware of her dyslexia, enjoyed language learning and compensated for her difficulties by studying extremely hard. She was, however, provided a lot of help in her family.

\section{References}

Brophy, J. E. 1987. Synthesis of research on strategies for motivating students to learn. Educational Leadership 45, 4:40-48.

Brown, H. D. 1990. M\&Ms for language classrooms? Another look at motivation. In Georgetown University Round Table on Language and Linguistics 1990,383393. Washington, DC: Georgetown University Press.

Brown, H. D. 1994. Teaching by principles. Englewood Cliffs, NJ: Prentice Hall.

Creemers, B. 1994. The effective classroom. London: Cassell.

Crookes, G., and R. Schmidt. 1991. Motivation: Reopening the research agenda. Language Learning 41: 469-512. 
Dodick, D. J. 1996. A study of the attitudes and motivation of high school foreign language students. Canadian Modern Language Review 52: 577-595.

Downey, D., L. Snyder, and B. Hill. 2000. College students with dyslexia: Persistent linguistic deficits and foreign language learning. Dyslexia $6: 101-111$.

Dörnyei, Z. 1994. Motivation and motivating in the foreign language classroom. Modern Language Journal 78 :273-284.

Dörnyei, Z. 2001a. Teaching and researching motivation. London: Longman.

Dörnyei, Z. 2001b. Motivational strategies. Cambridge: Cambridge University Press.

Dörnyei, Z. 2005. The psychology of the language learner: Individual differences in second language acquisition. Mahwah, NJ: Lawrence Erlbaum.

Dörnyei, Z., and K Csizér. 1998. Ten commandments for motivating language learners: Results of an empirical study. Language Teaching Research 2: 203229.

Dörnyei, Z., K. Csizér, and N. Németh, N. 2006. Motivational dynamics, language attitudes and language globalisation: A Hungarian perspective. Clevedon, UK: Multilingual Matters.

Edwards, J. 1994. The scars of dyslexia: Eight case studies in emotional reactions. London: Cassel.

Fletcher, J.M., G:R. Lyon, L.S. Fuchs, and M.A. Barnes. 2007. Learning disabilities: From identification to intervention. New York: Guilford.

Ganschow, L., and R. Sparks and J. Javorsky. 1998. Foreign language learning difficulties: An historical perspective. Journal of Learning Disabilities 31: 248-258.

Gósy, M. 1995. GMP-diagnosztika [GMP diagnostics]. Budapest: Nikol. 
Gyarmathy, É. And E. Vassné Kovács. 2004. Dyslexia in Hungary: A guide to practice and resources. International book of dyslexia. A cross language comparison and practice guide, ed. I. Smythe, J. Everatt, and R. Salter, 116121. British Dyslexia Association: Reading.

Guilloteaux, M. J., and Z. Dörnyei (2008). Motivating language learners: A classroom-oriented investigation of the effects of motivational strategies on student motivation. TESOL Quarterly 42: 55-77.

Horwitz, E. K., M. B. Horwitz, M. B. and J. Cope. 1986. Foreign language classroom anxiety. Modern Language Journal 70:125-132.

Juhász, Á. ed. 1999. Logopédiai vizsgálatok kézikönyve [The manual of examinations in speech therapy]. Budapest: Új Múzsa.

Kormos, J., and E. H. Kontra. 2008. Hungarian teachers' perceptions of dyslexic language learners. In Language learners with special needs: An international perspective, ed. J. Kormos and E. H. Kontra, 189-213. Clevedon: Multilingual Matters.

Kormos, J., K. Csizér, and Á. Sarkadi. (submitted). The dynamics of language learning motivation: Lessons from an interview study with dyslexic language learners. Modern Language Journal.

Lyon, G.R., S.E. Shaywitz, and B.A. Shaywitz. 2003. Defining dyslexia, comorbidity, teachers' knowledge of language and reading. A definition of dyslexia. Annals of Dyslexia $53: 1-14$.

Ndlovu, K., and E. Geva, E. 2008. Writing abilities in first and second language learners with and without reading disabilities. In Language learners with special needs: An international perspective, ed. J. Kormos and E. H. Kontra, 36-62. Clevedon: Multilingual Matters. 
Nijakowska, J. 2008. An experiment with direct multisensory instruction in teaching word reading and spelling to Polish dyslexic learners of English. In Language learners with special needs: An international perspective, ed. J. Kormos and E. H. Kontra, 130-157. Clevedon: Multilingual Matters.

Nikolov, M. 1999. "Why do you learn English?" "Because the teacher is short." A study of Hungarian children's foreign language motivation. Language Teaching Research 3: 33-56.

Noels, K., R. Clément and L.G. Pelletier 1999. Perceptions of teachers' communicative style and students' intrinsic and extrinsic motivation. Modern Language Journal 83: 23-34.

Oxford, R., and J. Shearin, J. 1994. Language learning motivation: Expanding the theoretical framework. Modern Language Journal 78: 12-28.

Oxford, R., and J. Shearin, J. 1996. Language learning motivation in a new key. In R. Oxford (Ed.), Language learning motivation: Pathways to the new century (Technical Report \#11, 155-187). Honolulu, HI: University of Hawai'i, Second Language Teaching \& Curriculum Center.

Price, M. L. 1991. The subjective experience of foreign language anxiety: Interviews with anxious students. In Language anxiety: From theory and research to classroom implications ed. E. K. Horwitz, and D. J. Young, 101-108. Englewood Cliffs, NJ:Prentice-Hall.

Ranaldi, F. 2003. Dyslexia and design and technology. London: David Fulton.

Robinson, P. 2005. Aptitude and second language acquisition. Annual Review of Applied Linguistics 2: 45-73.

Sarkadi, Á. 2005. Dyslexia and achieving success in studying English as a foreign language. Unpublished MA dissertation. Eötvös Loránd University. 
Sarkadi, Á 2008. Vocabulary learning in Dyslexia - The case of a Hungarian learner. In Language learners with special needs: An international perspective, ed. J. Kormos and E. H. Kontra, Clevedon: Multilingual Matters.

Schmidt, R., D. Boraie, and O. Kassabgy. 1996. Foreign language motivation: Internal structure and external connections. In Language learning motivation: Pathways to the new century ed. R. Oxford (Technical Report \#11, 9-70). Honolulu, HI: University of Hawai'i, Second Language Teaching \& Curriculum Center.

Schneider, E., and M. Crombie 2003. Dyslexia and foreign language learning. London: David Fulton.

Smith, A. M. 2008. Teachers' and trainers' perceptions of inclusion within TEFL certificate courses in Britain. In Language learners with special needs: An international perspective, ed. J. Kormos and E. H. Kontra, 214-233. Clevedon: Multilingual Matters.

Sparks, R.L., L. Ganschow, and J. Patton. 2008. L1 and L2 literacy, L1 and L2 aptitude, and L2 affective variables as discriminators among high- and lowAchieving, LD, and ADHD L2 learners In Language learners with special needs: An international perspective, ed. J. Kormos and E. H. Kontra, 11-35. Clevedon: Multilingual Matters.

Sparks, R., and L. Ganschow. 1993. The impact of native language learning problems on foreign language learning: Case study illustrations of the linguistic coding deficit hypothesis. Modern Language Journal 77, 58-74.

Sparks, R.L., M. Artzer, J. Patton, L. Ganschow, K. Miller, D. J. Hordubay and G. Walsh. 1998. Benefits of multisensory structured language instruction for atrisk foreign language learners: a comparison study of high school Spanish students. Annals of Dyslexia 48: 239-270. 
Williams, M., and L.R. Burden. 1997. Psychology for language teachers. Cambridge: Cambridge University Press. 
Table 1. The overview of the participants' biographical data

\begin{tabular}{|c|c|c|c|c|c|c|c|c|}
\hline & $\begin{array}{l}\text { Pseudo } \\
\text { name }\end{array}$ & Gender & Age & $\mathrm{L} 2$ & L3 & L4 & $\begin{array}{l}\text { Participants' } \\
\text { age at } \\
\text { diagnosis }\end{array}$ & Type of school \\
\hline 1. & Antal & boy & 22 & English & German & & 14 & $\begin{array}{l}\text { Mainstream } \\
\text { primary and } \\
\text { secondary } \\
\text { school, college }\end{array}$ \\
\hline 2. & Barbara & girl & 18 & German & English & & 6 & $\begin{array}{l}\text { Mainstream } \\
\text { primary and } \\
\text { secondary } \\
\text { school }\end{array}$ \\
\hline 3. & Csilla & girl & 28 & English & Russian & German & 27 & $\begin{array}{l}\text { Mainstream } \\
\text { primary and } \\
\text { secondary } \\
\text { school, college }\end{array}$ \\
\hline 4. & Dénes & boy & 20 & German & English & & 8 & $\begin{array}{l}\text { Mainstream } \\
\text { primary and } \\
\text { secondary } \\
\text { school }\end{array}$ \\
\hline 5. & Eszter & girl & 25 & English & Russian & & 23 & $\begin{array}{l}\text { Mainstream } \\
\text { primary and } \\
\text { secondary } \\
\text { school, } \\
\text { university }\end{array}$ \\
\hline 6. & Ferenc & boy & 27 & English & Greek & & 26 & $\begin{array}{l}\text { Mainstream } \\
\text { primary and } \\
\text { secondary } \\
\text { school, college }\end{array}$ \\
\hline 7. & Gábor & boy & 14 & English & Spanish & & 10 & $\begin{array}{l}\text { Mainstream } \\
\text { primary school } \\
\text { with special } \\
\text { classes for LD }\end{array}$ \\
\hline 8. & Helga & girl & 16 & English & Italian & & 13 & $\begin{array}{l}\text { Mainstream } \\
\text { primary and } \\
\text { secondary } \\
\text { school }\end{array}$ \\
\hline 9. & Ilona & girl & 15 & English & Hebrew & $\begin{array}{l}\text { Spanish, } \\
\text { German }\end{array}$ & 12 & $\begin{array}{l}\text { Regular primary } \\
\text { and secondary } \\
\text { school with a } \\
\text { special L2 } \\
\text { program for LD }\end{array}$ \\
\hline 10. & József & boy & 15 & English & Russian & & 7 & $\begin{array}{l}\text { Mainstream } \\
\text { primary and } \\
\text { secondary } \\
\text { school }\end{array}$ \\
\hline
\end{tabular}




\begin{tabular}{|c|c|c|c|c|c|c|c|c|}
\hline & $\begin{array}{l}\text { Pseudo } \\
\text { name }\end{array}$ & Gender & Age & L2 & L3 & L4 & $\begin{array}{l}\text { Participants' } \\
\text { age at } \\
\text { diagnosis }\end{array}$ & Type of school \\
\hline 11. & Konrád & boy & 17 & English & German & & 7 & $\begin{array}{lr}\text { Special primary } \\
\text { and secondary } \\
\text { school } \\
\text { students } \\
\text { LD with }\end{array}$ \\
\hline 12. & Lajos & boy & 18 & English & German & & 13 & $\begin{array}{l}\text { Special primary } \\
\text { and secondary } \\
\text { school } \\
\text { students } \\
\text { LD with } \\
\end{array}$ \\
\hline 13. & Miklós & boy & 16 & German & English & & 10 & \begin{tabular}{lr}
\multicolumn{2}{l}{ Mainstream } \\
primary and \\
special \\
secondary \\
school for \\
students with \\
LD
\end{tabular} \\
\hline 14. & Norbert & boy & 19 & English & Serbian & & 12 & $\begin{array}{l}\text { Mainstream } \\
\text { primary and } \\
\text { special } \\
\text { secondary } \\
\text { school for } \\
\text { students with } \\
\text { LD }\end{array}$ \\
\hline 15. & Péter & boy & 16 & English & & & 13 & $\begin{array}{l}\text { Mainstream } \\
\text { primary and } \\
\text { special } \\
\text { secondary } \\
\text { school for } \\
\text { students with } \\
\text { LD }\end{array}$ \\
\hline
\end{tabular}


Table 2 An overview of students' views concerning their school teacher general behavior in class

\begin{tabular}{|l|l|l|}
\hline Participant & $\begin{array}{l}\text { Positive attitude to teacher } \\
\text { (Number of comments) }\end{array}$ & $\begin{array}{l}\text { Negative attitude to } \\
\text { teacher } \\
\text { (Number of comments) }\end{array}$ \\
\hline A & 2 & 3 \\
\hline B & 2 & 1 \\
\hline C & 1 & 3 \\
\hline D & 1 & 2 \\
\hline E & 1 & 2 \\
\hline F & 0 & 1 \\
\hline G & 4 & 0 \\
\hline H & 1 & 5 \\
\hline I & 5 & 0 \\
\hline J & 2 & 6 \\
\hline K & 2 & 0 \\
\hline L & 2 & 2 \\
\hline M & 2 & 1 \\
\hline N & 2 & 2 \\
\hline P & 1 & 2 \\
\hline Total & 28 & 28 \\
\hline
\end{tabular}


Figure 1 The emerging model of the relationship of students' language learning experience and motivation

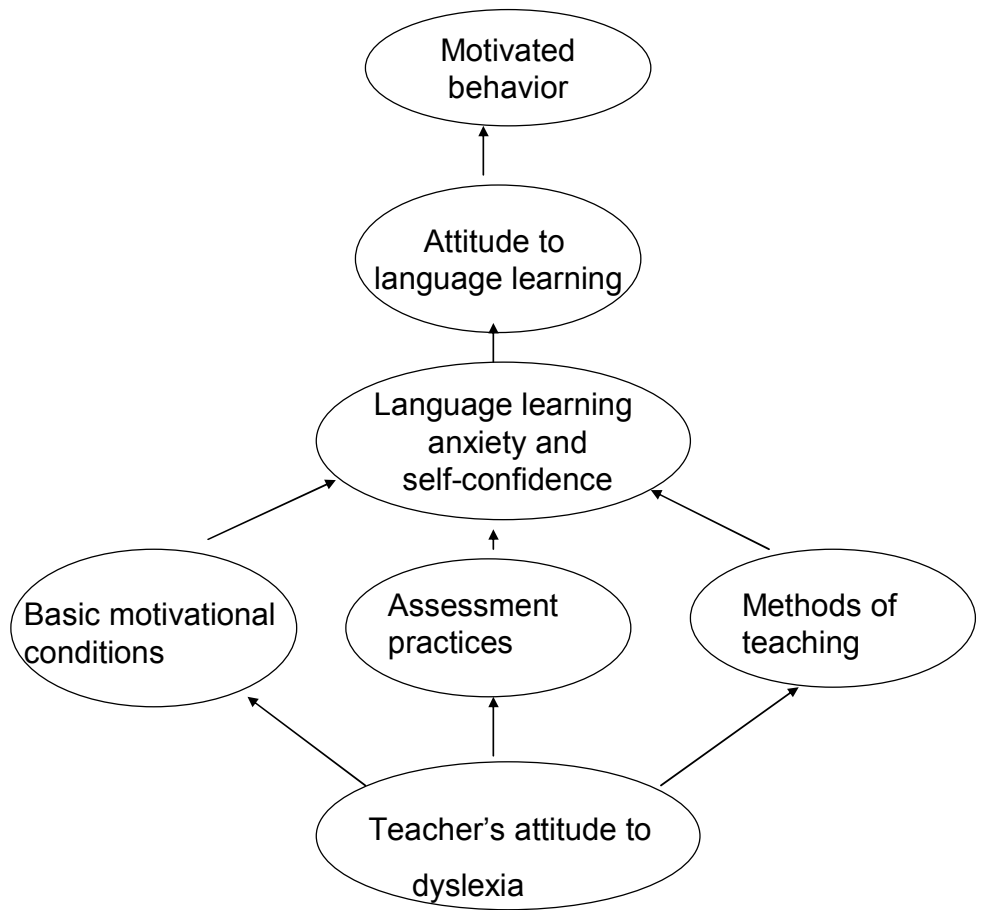

